\title{
Clinical features and management of recurrent balanitis; association with atopy and genital washing
}

H D L Birley, M M Walker, G A Luzzi, R Bell, D Taylor-Robinson, M Byrne, A M Renton

\begin{abstract}
Objective-To evaluate clinical features and diagnostic investigations in patients with recurrent or unresponsive balanitis in order to institute rational management.

Design-Forty-three patients presenting to a genitourinary medicine clinic with recurrent or persistent balanitis were studied. All patients were asked whether they had a history of atopic illness and about their practice of genital washing. All patients were investigated by taking a swab specimen from the preputial area for bacterial and viral culture and 30 underwent biopsy of the affected skin. Follow-up was between three and six months.
\end{abstract}

Setting-Outpatient genitourinary medicine clinic, St Mary's Hospital, London, UK.

Results-In $31(72 \%)$ of the patients a diagnosis of irritant dermatitis was made. In comparison with the remaining patients, they had a greater lifetime incidence of atopic illness and more frequent daily genital washing with soap. For 28 $(90 \%)$ of these patients, use of emollient creams and restriction of soap washing alone controlled symptoms satisfactorily. For the remaining 12 patients, a variety of diagnoses were made. Biopsy proved a well tolerated and diagnostic investigation, but the isolation of microbial pathogens from preputial swabs was irrelevant to management.

Conclusion-A history of atopic illness and of the practice of penile washing are important aspects in the evaluation of patients with recurrent balanitis. Biopsy is an important investigation in the condition when it does not seem to be caused by irritant dermatitis.

(Genitourin Med 1993;69:400-403)

\section{Introduction}

Balanitis is a common condition. At the Jefferiss Wing walk-in Genitourinary Medicine clinic at St Mary's Hospital, Paddington there were 2006 male attendances for conditions requiring treatment in a 3 month period in 1992. Of these, 234 (11\%) were diagnosed as balanitis. Furthermore, in a review of 100 men presenting consecutively at this clinic, 32 had been treated for balanitis at least twice in the previous six months Nevertheless, despite its frequency, this condition often receives scant attention. In some cases, there is a clearly defined cause for balanitis, for example a generalised skin condition in which balanitis is a component. ${ }^{12}$ In many cases, however, the cause is assumed to be fungal and the patient treated with repeated courses of topical antifungal creams. Our aim was to study patients with recurrent or stubborn problems in which a cause had not been identified in an attempt to establish a firm diagnosis and institute rational management.

\section{PATIENTS AND METHODS}

Forty-three consecutive patients who had had two or more episodes of itching or soreness of the preputial or glans area within the previous six months, or who had not responded to topical antifungal creams were recruited into the study. Local ethical committee approval had been granted and signed consent was obtained from the patients. No topical treatment was given for at least two weeks before assessment. Time was allocated for careful history taking, including a personal or family history of atopic disease (eczema, hayfever or asthma) and information about the patient's usual practice of genital washing. Patients were examined for the presence of rashes both within and outside the anogenital area and swabs were taken from the preputial sac for bacterial, fungal and herpes simplex virus (HSV) culture by routine diagnostic methods. All patients were screened serologically for syphilis (VDRL and TPHA), for gonorrhoea by gram stain and culture of an urethral swab and for the presence of a purulent urethral discharge (defined as more than 5 neutrophils per high-power field on microscopy of an urethral smear). A $2 \mathrm{~mm}$ pinch biopsy specimen was taken from an inflamed area of the prepuce or glans of 30 of the patients using a technique described previously. ${ }^{3}$ Apart from five patients, whose biopsy sites took up to four weeks to heal completely, the remainder had healed within two weeks, and there were no complications. Biopsy specimens were fixed in formalin, processed routinely and sections stained by haematoxylin and PAS were examined by a single histopathologist (MMW). All patients were reviewed monthly in the clinic for between three and six months and they were encouraged to self-refer in case of relapse or new symptoms. 


\section{Results}

CHARACTERISTICS OF PATIENTS AND PREVIOUS TREATMENT

Forty-three men, mean age 35 years (range 20-77 years), of whom five were homosexual, were seen with balanitis that had been present for a mean period of 18 months (range 1-96 months). Sixteen of the men had previously received topical imidazole (antifungal) creams, two patients had received topical steroid creams and eight topical preparations of combined steroid and imidazole. No patient had serological evidence of syphilis or a positive culture or microscopy for gonorrhoea. Five patients had microscopic evidence of an urethral discharge. All had florid balanitis at the time and none had detectable urethral pus on repeat testing two weeks later when the balanitis had settled. No patient had a history or signs of arthritis or conjunctivitis suggestive of Reiter's syndrome.

\section{HISTOLOGICAL DIAGNOSES}

The results of histological analysis of biopsy specimens from 30 patients are shown in table 1 . In specimens from 18 patients, there was a patchy, principally perivascular chronic inflammatory infiltrate in the dermis, often with oedema and spongiosis of the epidermis consistent with a diagnosis of non-specific dermatitis (NSD). ${ }^{4}$ Of the specimens from the remaining 12 patients, four had histological evidence of human papillomavirus (HPV) infection, including hyper-keratosis and parakeratosis as well as koilocytosis; additional dysplastic changes were observed in two of these (PIN1 and PIN2). A variety of other diagnoses based on histological changes, were ascribed to the remaining eight patients.

\section{MICROBIOLOGICAL FINDINGS}

The results of the microbiological investigations are shown in table 2. Organisms which are usually not found in the normal skin flora were cultured from some of the preputial swabs. Thus, various streptococci were isolated from three patients with a histological diagnosis of NSD and Staphylococcus aureus with herpes simplex virus from the fourth NSD patient. Candida albicans was recovered from the swab of the patient whose balanitis was ascribed to this organism and Pseudomonas aeruginosa and herpes simplex virus from the patient with plasma cell balanitis. No organisms were cultured from the other patients who were biopsied or from the unbiopsied group.

Table 1 Histological features of biopsy specimens

\begin{tabular}{lll}
\hline Histological features & & $\begin{array}{l}\text { Number of } \\
\text { patients }\end{array}$ \\
\hline Dermatitis: non-specific & Lichen sclerosus & 18 \\
Dermatosis: specific & 2 \\
& Lichen planus & 1 \\
& Plasma cell balanitis & 1 \\
Dermatosis: infective & Dermatitis artefacta & 2 \\
& Post scabetic & 1 \\
& Candida & 1 \\
& Wart virus & 2 \\
Wart virus & 2 \\
Total & with dysplasia & 30 \\
\hline
\end{tabular}

Table 2 Recovery of micro-organisms from preputial swabs in relation to histological diagnosis

\begin{tabular}{lll}
\hline Micro-organism & $\begin{array}{l}\text { Number of } \\
\text { patients }\end{array}$ & $\begin{array}{l}\text { Histological } \\
\text { diagnosis }\end{array}$ \\
\hline $\begin{array}{l}\text { BACTERIA } \\
\text { Group A Streptococcus }\end{array}$ & 1 & $\begin{array}{l}\text { Non-specific } \\
\text { dermatitis (NSD) } \\
\text { NSD }\end{array}$ \\
$\begin{array}{l}\text { Group B Streptococcus } \\
\begin{array}{l}\text { Streptococcus milleri } \\
\text { Staphylococcus aureus } \\
\text { and Herpes simplex }\end{array}\end{array}$ & 1 & NSD \\
$\begin{array}{l}\text { Pseudomonas aeruginosa } \\
\text { and Herpes simplex }\end{array}$ & 1 & NSD \\
$\begin{array}{l}\text { FUNGI } \\
\text { Candida albicans }\end{array}$ & 1 & $\begin{array}{l}\text { Plasma cell } \\
\text { balanitis }\end{array}$ \\
$\begin{array}{l}\text { VIRUSES } \\
\text { Herpes simplex }\end{array}$ & 2 & $\begin{array}{l}\text { Candidal } \\
\text { balanitis }\end{array}$ \\
& & $\begin{array}{l}\text { NSD (1) } \\
\text { Plasma cell } \\
\text { balanitis (1) }\end{array}$ \\
\hline
\end{tabular}

RELATION BETWEEN HISTOLOGICAL DIAGNOSIS AND CLINICAL FEATURES

Patients with NSD. Observations on 18 patients with a histological diagnosis of NSD are shown in table 3. Of these, 12 (67\%) had a history of atopy, a significantly greater proportion than noted for patients with other histological diagnoses $(p<0.02$, Fisher's exact test). In all but one of the former group, there was a history of frequent genital washing with soap or shower gel and the mean number of daily washings was larger in this group than in the other patients. In addition, 11 patients had an eczematous rash elsewhere on the body. Six (33\%) were circumcised. In 14 of the 18 patients, symptoms fluctuated with an onset within 24 hours. None of the other patients biopsied gave a history of fluctuating symptoms. Five patients ascribed relapses to sexual activity but all had also increased their frequency of penile washing after intercourse.

Patients with other histological diagnoses. In the remaining 12 patients who were subjected to biopsy, the histological examination provided a specific diagnosis (table 1). Although the lower lifetime incidence of atopy and lower frequency of genital washing (table 3) helped to distinguish these patients from those with NSD, the clinical appearance of the rash was often not pathognomonic and other investigations, particularly histological examination of the biopsy specimen, were important in making the correct diagnosis.

Table 3 Relation between histological diagnosis and clinical features

\begin{tabular}{|c|c|c|c|}
\hline $\begin{array}{l}\text { Histological } \\
\text { category }\end{array}$ & $\begin{array}{l}\text { Non-specific } \\
\text { dermatitis }\end{array}$ & $\begin{array}{l}\text { Other } \\
\text { histology }\end{array}$ & $\begin{array}{l}\text { All } \\
\text { patients }\end{array}$ \\
\hline $\begin{array}{l}\text { Number of } \\
\text { patients }\end{array}$ & 18 & 12 & 43 \\
\hline $\begin{array}{l}\text { Mean Age (years) } \\
\text { (Range) }\end{array}$ & $\begin{array}{l}36 \\
(24-60)\end{array}$ & $\begin{array}{l}33 \\
(27-77)\end{array}$ & $\begin{array}{l}35 \\
(20-77)\end{array}$ \\
\hline $\begin{array}{l}\text { Number with a } \\
\text { history of } \\
\text { atopy } \\
(\%)\end{array}$ & $\begin{array}{l}12 \\
(67)\end{array}$ & $\begin{array}{l}2 \\
(17)\end{array}$ & $\begin{array}{l}23 \\
(53)\end{array}$ \\
\hline $\begin{array}{l}\text { Mean number } \\
\text { of washes } \\
\text { /day } \\
\text { (range) }\end{array}$ & $\begin{array}{l}2 \cdot 7 \\
(1-7)\end{array}$ & $\begin{array}{l}1 \cdot 2 \\
(1-2)\end{array}$ & $\begin{array}{l}1 \cdot 6 \\
(1-7)\end{array}$ \\
\hline $\begin{array}{l}\text { Number } \\
\text { circumcised }\end{array}$ & 6 & 2 & 10 \\
\hline
\end{tabular}


For example, in the single patient who had a proven diagnosis of candidal infection, C. albicans was cultured from the subpreputial swab specimen and fungal hyphae were visible in the superficial epidermis of the biopsied skin, and, in addition, glycosuria and a random blood glucose of $15 \mathrm{mM}$ were found; the patient had previously unsuspected diabetes mellitus. In some cases, histological examination of the biopsy specimen helped to elicit previously undisclosed details of the history. Thus, the two patients with dermatitis artefacta admitted to abrading the glans only after being told that the result of examining the biopsy specimen suggested this.

\section{Management of patients}

Management of patients with NSD. Patients with a histological diagnosis of NSD were advised to restrict use of soap and were prescribed emollient cream (E45 cream; Crookes products, UK) for use twice daily. This completely prevented further episodes of balanitis in all but three of the patients who responded to topical hydrocortisone cream 1\% applied three times daily for one week. Two patients needed a repeat course of topical steroid during the period of follow-up.

In view of the success of this regimen, and the emergence of clinical recognition of irritant dermatitis, ${ }^{5}$ a further 13 patients who attended the clinic with a similar history and rash were managed without recourse to biopsy. Putative pathogenic organisms were not isolated from the preputial sac swabs of any of these patients and all of them responded satisfactorily.

Management of patients with other histological diagnoses. Management of those patients with histological features other than those of NSD was often critically dependent upon the histological features of the biopsy specimen. The patient with candidal balanitis was treated with topical imidazole cream (Clotrimazole $1 \%$, "Canesten"; Bayer, UK) and was referred for further management of his diabetes. The two patients with dermatitis artefacta were cured promptly by a one week course of moderate potency steroid cream (Clobetasone butyrate 0.05\%, "Eumovate"; Glaxo, U.K.) and instructions to discontinue abrasion. The patient with plasma cell balanitis had been treated previously with oral antiviral medication (acyclovir $200 \mathrm{mg}$ five times a day for five days) and topical neomycin ointment in view of the isolation of $\mathrm{HSV}$ and pseudomonas but showed no improvement. Both this patient and the patients with lichen sclerosus were referred for circumcision with great improvement. Both the patient with lichen planus and the patient with post-scabetic dermatitis improved over four weeks with an anti-pruritic cream (Crotamiton $10 \%$, 'Eurax'; Ciba Consumer, UK).

The two patients with HPV-related changes and the patient with PIN1 on biopsy were treated with E45 cream. Although the patients reported no immediate relief, the symptoms and signs of inflammation resolved gradually over the period of follow-up. The patient with PIN2 had small discrete areas of patchy inflammatory change and these were ablated with diathermy with resolution of symptoms. No follow-up biopsies have been performed on the normal appearing skin.

\section{Discussion}

The 43 patients in this study were a consecutive series and are representative of the patients attending this clinic with the problem of chronic or recurrent balanitis. Our observations indicate that this entity has multiple causes including metazoon, fungal and viral infections together with premalignancy. However, irritant dermatitis was found to be the most common cause. The ability to identify the cause in a particular case aids rational management considerably and biopsy of the affected skin proved an important diagnostic investigation for our patients. Biopsy was also a well tolerated procedure in this as in previous series. ${ }^{36}$ Although patients initially were often unsure about undergoing biopsy, many felt reassured by the histological diagnosis that it provided.

A history of fluctuating episodes, with a rapid onset, as well as that of atopy and of zealous washing were predictive of a histological diagnosis of NSD. The proportion of NSD patients with a history of atopy $(67 \%)$ was much larger than that in the general population. ${ }^{7}$ It is possible that the balanitis was due to hypersensitivity to a specific allergen, ${ }^{8}$ but we could ascribe it to nothing other than frequent soap washing. Dermatological and generalised hypersensitivity to allergens encountered during sexual activity are well described $^{9}$ but in this series, washing after sexual intercourse could easily have explained the association.

Bacterial pathogens have been implicated as a cause of balanitis in previous series ${ }^{1011}$ and they could act as allergens, but in our patients it is far from clear whether the isolates from preputial swabs were involved in the inflammatory process or were merely incidental to it. The latter seems likely since although bacterial pathogens were isolated from four of the 18 patients with a diagnosis of NSD, recovery swiftly followed the use of emollient creams only and no specific further treatment was required.

Circinate balanitis is associated with Reiter's syndrome but no biopsy specimen had histological features to suggest this diagnosis and no patient had arthritis or conjunctivitis. Five patients had more than five pus cells seen in a high power field of an urethral smear which is usually taken as evidence of urethritis. All of these patients had florid balanitis which resolved after two weeks of treatment with an emollient cream and none had pus cells on a further urethral smear taken at this time. Because none of these patients was treated with antibiotics, it is unlikely that any had an infection such as chlamydial urethritis. Instead, the pus cells seen in the first smear 
were probably due to contamination from the acute balanitis.

Circumcision, so commonly recommended in children with recurrent balanitis, might be of benefit in a patient whose balanitis relapses despite these measures, ${ }^{12}$ and remains the principal treatment for specific conditions such as lichen sclerosus and plasma cell balanitis. ${ }^{13}$ However, in our series, six out of the 18 patients with NSD had been circumcised so the condition seems not to be confined to uncircumcised men.

It was a feature of this study that balanitis in the NSD patients responded readily to the regular application of emollients when advice to cut down on washing was heeded. Only three of the 18 histologically proven cases required any further treatment and all three patients responded to low potency steroid creams applied for a few days. In view of this, and because of the relative frequency of NSD as a diagnostic category in our series. 13 subsequent patients were treated empirically with emollients without prior biopsy to determine the histological features. The symptoms in all of these patients were well controlled when they were seen during follow-up (3-6 months).

The experience we have gained from this series suggests that an empirical trial of emollient creams combined with advice to reduce frequent washing with soap is an appropriate first line management for patients with recurrent balanitis rather than the vastly more expensive topical imidazole preparations. Biopsy might then be reserved for those patients who do not respond well to this regime.

Dr Birley is supported by a grant from the North-West Thames Regional Health Authority

1 Stolz E, Menke HE, Vuzevski VD. Other Genital Dermatoses. In: Holmes KK, Mardh P-A, Sparling PF, et al, eds. Sexually Transmitted Diseases 2nd ed. New York: McGraw-Hill Information Services Company.

Vohra S, Badlani G. Balanitis and balanoposthitis. Urol Clin North Am 1992;19:143-7.

3 Hillman RJ, Walker MM, Harris JRW, Taylor-Robinson D. Penile dermatoses: a clinical and histopathological study. Genitourin Med 1992;68:166-9.

4 Lever WF, Schaumberg-Lever G. Histopathology of the Skin 7th ed. Philadelphia: JB Lippincott Company, 1990.

5 Rycroft RRG, Wilkinson JD. Irritants and Sensitizers. In: Champion RH, Burton JL, Ebling FJG eds. Textbook of Dermatology 5th ed. Oxford: Blackwell 1992;717-55.

6 Arumainayagam JT, Sumathipala AHT. Value of performing biopsies in genitourinary clinics. Genitourin Med 1990;66:407.

7 Mcfadden E R, Gilbert I A. Medical Progress: Asthma. N Engl ₹ Med 1992;327:1928-38.

8 Fisher AA. Reactions of the mucous membrane to contactants. Clin Dermatol 1987;5:123-36.

9 Sonnex C. Sexual hypersensitivity. Br f Hosp Med 1988; 39:40-8.

10 Abdullah AN, Drake SM, Wade AA, Walzman $M$. Balanitis (balanoposthitis) in patients attending a department of genitourinary medicine. Int $\mathcal{f} S T D$ AIDS 1992;3:128-9.

11 Kyriazi NC, Costenbader CL. Group A beta-hemolytic streptococcal balanitis: it may be more common than you think. Pediatrics 1991;88:154-6.

12 Fakjian N, Hunter S, Cole GW, Miller J. An argument for circumcision. Prevention of balanitis in the adult. Arch Dermatol 1990;126:1046-7.

13 Gordon A, Collin J. Save the normal foreskin. BMF (Editorial) 1993;306:1-2. 